(C) 2022, The Authors. Published by Elsevier Inc. and Fass Inc. on behalf of the American Dairy Science Association ${ }^{\circledR}$. This is an open access article under the CC BY license (http://creativecommons.org/licenses/by/4.0/).

\title{
Effect of injectable trace mineral supplementation on peripheral polymorphonuclear leukocyte function, antioxidant enzymes, health, and performance in dairy cows in semi-arid conditions
}

\author{
T. H. Silva, ${ }^{1,2}$ I. Guimaraes, ${ }^{1}$ P. R. Menta, ${ }^{1}$ L. Fernandes, ${ }^{1}$ D. Paiva, ${ }^{1}$ T. L. Ribeiro, ${ }^{1}$ M. L. Celestino, ${ }^{1}$ \\ A. Saran Netto, ${ }^{2}$ M. A. Ballou, ${ }^{1}$ and V. S. Machado ${ }^{1 *}$ \\ ${ }^{1}$ Department of Veterinary Sciences, Texas Tech University, Lubbock 79415 \\ ${ }^{2}$ Department of Animal Science, School of Animal Science and Food Engineering, University of Sao Paulo, Pirassununga, SP $13635-900$ Brazil
}

\begin{abstract}
The objective of this study was to evaluate the effect of subcutaneous injections of $15 \mathrm{mg} / \mathrm{mL} \mathrm{Cu}, 5 \mathrm{mg} /$ $\mathrm{mL} \mathrm{Se}, 60 \mathrm{mg} / \mathrm{mL} \mathrm{Zn}$, and $10 \mathrm{mg} / \mathrm{mL} \mathrm{Mn}$ on health, performance, polymorphonuclear leukocyte (PMNL) function, circulating glutathione peroxidase (GPx) and superoxide dismutase (SOD) concentrations, and inflammation of dairy cows undergoing the transition period in high temperature-humidity index. A total of 923 multiparous cows from 2 commercial dairy farms were randomly allocated into 1 of 2 treatment groups as follows: control and injectable trace mineral supplementation (ITMS). Cows in the ITMS group received $7 \mathrm{~mL}$ of subcutaneous injections at dry-off $(208 \pm 3$ d of gestation), $260 \pm 3 \mathrm{~d}$ of gestation, and at $35 \pm 3$ $\mathrm{d}$ in milk (DIM). Data regarding health traits, reproductive performance, milk yield, and survivability were extracted from farm database software, and animals were followed-up until 300 DIM. For a subset of 142 cows from one herd, blood samples were collected at enrollment, and at $3 \pm 1,7 \pm 1,10 \pm 1$, and $35 \pm$ 3 DIM to evaluate hematology, PMNL function, GPx and SOD concentrations, and circulating haptoglobin. Logistic regression was used to assess health and pregnancy per artificial insemination at first service. Cox proportional hazards models were used to evaluate hazard of pregnancy and culling. Mixed linear regression models accounting for repeated measures were used to assess all continuous variables collected over time. Parity, twinning, and previous gestation length were considered as potential confounders. Farm was included as a random effect. The ITMS cows tended to have lower incidence of metritis and stillbirth compared with control group. However, ITMS treatment did not influence the incidence of other diseases (e.g., mastitis, re-
\end{abstract}

Received April 18, 2021.

Accepted September 28, 2021.

*Corresponding author: vinicius.machado@ttu.edu tained placenta), milk yield, reproductive performance, culling, and leukocyte count. Neutrophil-to-lymphocyte ratio, PMNL phagocytosis, and oxidative burst as well as intensity of the oxidative burst were greater for ITMS-treated cows in comparison to control cows. The ITMS cows had decreased expression of the adhesion molecule L-selectin on PMNL surface. The serum concentration of GPx and SOD were not affected by ITMS treatment. In conclusion, ITMS tended to reduce the incidence of metritis and stillbirth parturition, improved PMNL function, and improved the inflammatory status of dairy cows undergoing the transition period in high temperature-humidity index conditions. However, these findings did not translate into improved milk yield, reproductive performance, and survivability. Key words: trace mineral, dairy cow, immune function, health

\section{INTRODUCTION}

During the transition period, from 3 wk before to 3 wk after parturition, dairy cows face an impairment or dysregulation of their immune function, which has been recognized as a central element to the development of diseases, such as metritis and mastitis (LeBlanc, 2020). Concurrently, during the periparturient period, dairy cows experience a substantial increase in oxygen consumption that results in elevated production of reactive oxygen species (ROS; Sordillo, 2016). Therefore, an imbalance between the production of ROS and the availability of antioxidant defenses may expose these animals to oxidative stress (Sordillo and Aitken, 2009). Additionally, heat stress has been reported to aggravate this scenario, whereas cows can experience greater degrees of feed intake depression (Adin et al., 2009), increased degree of oxidative stress (Bernabucci et al., 2002; Safa et al., 2019), and immune dysregulation (Lacetera et al., 2005; Lecchi et al., 2016; Safa et al., 2019). High proportion of puerperal disorders have been observed in dairy cows undergoing the transition 
period in heat-stress conditions (Gernand et al., 2019). Heat stress in dairy cows is particularly important in dairy herds located in semi-arid regions. For instance, in the southwest region of the High Plains in the United States or Northern Mexico, where the dairy industry is an important part of the local economy, the average temperature-humidity index (THI) during the summer is above 68, a number commonly used as the threshold for stress in dairy cows (Zimbelman et al., 2009).

Thermal environmental conditions may affect the immune system by complex mechanisms including body temperature change, behavioral and hormonal adaptation, circulatory adjustment, and oxidative stress (Lacetera, 2012). Shi et al. (2020) found significant changes of immunoglobulin and cytokine concentration and immune-related gene expression in heat-stressed lambs. Additionally, the authors detected reduced antioxidant enzyme activity coupled with oxidative stress status, which might be through ROS overproduction caused by hyperthermal stress. Providing shade and soaking lines are strategies commonly adopted to improve the performance and immune status of postpartum dairy cows undergoing heat stress (do Amaral et al., 2011). Also, supplementation of $\mathrm{Zn}, \mathrm{Mn}, \mathrm{Cu}$, and Se, which are components of antioxidant enzymes such as glutathione peroxidase (GPx) and superoxide dismutase (SOD), have been studied as alternative strategies to alleviate detrimental effects of heat stress on immunity, antioxidant status, and performance of chicken (Abd El-Hack et al., 2017; Rajkumar et al., 2018) and sheep (Alhidary et al., 2015). Hence, it is plausible that trace mineral supplementation can also help to mitigate the adverse effects caused by the burden of heat stress in other livestock such as dairy cows. Because of dietary deficiency of $\mathrm{Zn}, \mathrm{Cu}, \mathrm{Mn}$, and Se in dairy cows, either through antagonisms or imbalanced diets, the supplementation of these trace minerals has been intensively studied in dairy cattle (Overton and Yasui, 2014).

The use of injectable trace mineral supplementation (ITMS) with $\mathrm{Zn}, \mathrm{Mn}, \mathrm{Cu}$, and Se improved health (Machado et al., 2013) and serum SOD concentration of dairy cows (Machado et al., 2014) when supplemented at dry-off, $30 \mathrm{~d}$ before calving, and during the second month of lactation. However, Bicalho et al. (2014) did not detect differences in GPx and SOD activities when administrating 2 injections of trace minerals at 230 and $260 \mathrm{~d}$ of gestation. Additionally, postpartum polymorphonuclear leukocyte (PMNL) function, milk yield, and reproductive performance were not influenced by ITMS. Those studies were performed in dairy herds located in New York during cold-weather conditions. Because the concentration of ROS-scavenging trace mineral-dependent enzymes may increase under heat- stress conditions (Rhoads et al., 2013), ITMS in cows under heat stress could lead to different outcomes.

Therefore, the objective of this study was to evaluate the effect of an ITMS containing $\mathrm{Cu}, \mathrm{Se}, \mathrm{Zn}$, and $\mathrm{Mn}$ at dry-off ( $208 \pm 3$ d of gestation), $260 \pm 3$ d of gestation, and $35 \pm 3 \mathrm{~d}$ postpartum on incidence of postpartum diseases, milk yield, reproductive performance, culling, hematological parameters, PMNL activity, GPx and SOD concentrations, and circulating haptoglobin $(\mathbf{H p})$ in dairy cows undergoing the transition period in high THI.

\section{MATERIALS AND METHODS}

\section{Farms, Management, and Environmental Data}

All experimental procedures were approved by the Texas Tech University Institutional Animal Care and Use Committee (\#19045-05). This study was conducted on 2 commercial Holstein dairy farms (farm A and farm B) located in west Texas. Farms were selected based on their geographical location (near Lubbock, TX), and willingness to participate in the study. Cows were enrolled from April 30 until July 23, 2019; the follow-up period continued until November 13, 2019. The enrollment period was selected to maximize the number of days with THI >68 during the transition period. The environmental information was assessed from the Lubbock Airport's meteorological station because of its proximity to both dairies (67 and $48 \mathrm{~km}$ from farms A and $\mathrm{B}$, respectively). Daily temperature and relative humidity data were downloaded from Weather Underground (https://www.wunderground.com/history/ daily/us/tx/lubbock) from April 30 through November 13, 2019. The THI throughout the study period was calculated from the equation developed by the National Research Council (NRC, 1971) below as indicated by Dikmen and Hansen (2009):

$$
\begin{aligned}
\mathrm{THI}=(1.8 \times \mathrm{T}+32)-[(0.55-0.0055 \times \mathrm{RH}) \\
\left.\times\left(1.8 \times \mathrm{T}^{\circ} \mathrm{C}-26\right)\right],
\end{aligned}
$$

where $\mathrm{T}=$ ambient dry bulb temperature in ${ }^{\circ} \mathrm{C}$, and $\mathrm{RH}=$ relative humidity in \% . Meteorological data are presented in Figure 1.

Farm A milked 2,700 Holstein cows twice a day in a double 30-stall parallel milking parlor. The cows were housed in dry-lot pens, consisting of nonvegetated open lots (i.e., corrals) with shaded areas. Farm B milked 3,700 Holstein cows 3 times daily in a 70-stall rotary milking parlor. During the dry period, the animals were housed in dry-lot pens, consisting of nonvegetated open lots. After calving, the cows were housed in freestall 
Table 1. Chemical composition of pre-fresh and fresh cow diets (\% of DM, otherwise stated)

\begin{tabular}{|c|c|c|c|c|}
\hline \multirow[b]{2}{*}{ Item } & \multicolumn{2}{|c|}{ Farm A } & \multicolumn{2}{|c|}{ Farm B } \\
\hline & Pre-fresh ${ }^{1}$ & Fresh $^{2}$ & Pre-fresh & Fresh \\
\hline DM, \% & 59.2 & 47.8 & 47.2 & 47.8 \\
\hline $\mathrm{CP}$ & 14.8 & 18.7 & 13.1 & 17.6 \\
\hline Soluble protein, \% CP & 43.8 & 34.1 & 32.6 & 34.6 \\
\hline $\mathrm{ADF}$ & 23.5 & 20.6 & 28.5 & 17.4 \\
\hline NDF & 35.2 & 31.4 & 39.2 & 27.7 \\
\hline NFC & 37.8 & 36.4 & 34.1 & 41.9 \\
\hline Starch & 24.9 & 23.9 & 24.5 & 27.0 \\
\hline Calcium & 1.33 & 0.93 & 0.73 & 0.99 \\
\hline Phosphorus & 0.34 & 0.44 & 0.3 & 0.37 \\
\hline Magnesium & 0.42 & 0.37 & 0.28 & 0.35 \\
\hline Potassium & 1.7 & 1.53 & 1.09 & 1.62 \\
\hline Sodium & 0.17 & 0.34 & 0.13 & 0.74 \\
\hline Sulfur & 0.25 & 0.3 & 0.25 & 0.22 \\
\hline Chloride & 1.78 & 0.69 & 0.5 & 0.73 \\
\hline Iron, $\mathrm{mg} / \mathrm{kg}$ & 437 & 366 & 978 & 469 \\
\hline Zinc, $\mathrm{mg} / \mathrm{kg}$ & 103 & 57 & 49 & 104 \\
\hline Copper, $\mathrm{mg} / \mathrm{kg}$ & 27 & 15 & 8 & 18 \\
\hline Manganese, $\mathrm{mg} / \mathrm{kg}$ & 92 & 51 & 49 & 57 \\
\hline Selenium, $\mathrm{mg} / \mathrm{kg}$ & 0.62 & 0.43 & 0.39 & 0.62 \\
\hline
\end{tabular}

${ }^{1}$ Pre-fresh diets were fed from 3 wk prepartum through parturition.

${ }^{2}$ Fresh diets were fed from parturition through wk 35 postpartum.

barns with concrete stalls and bedded with manure solids without fans and soaking lines. At both farms, the animals were fed a TMR ad libitum with free access to water. According to herd characteristics, the diets were formulated to meet or exceed the NRC (2001). Composite TMR samples from pre-fresh and lactation diets were submitted to a commercial laboratory (Cumberland Valley Analytical Services Inc., Waynesboro, PA). Near-infrared spectroscopy was used to measure $\mathrm{DM}, \mathrm{CP}, \mathrm{ADF}$, and NDF. Macro and trace minerals, except Se, were analyzed by inductively coupled plasma
MS (AOAC International, 2000; method 985.01). Selenium was assessed by fluorometric method (AOAC International, 2005; method 996.16). Nutrient contents of the diets are described in Table 1.

\section{Sample Size Calculation}

Sample size calculation was undertaken in MedCalc version 18.11.6 (MedCalc Software). Based on previously reported data (Machado et al., 2013), we assumed that ITMS would decrease the incidence of clinical

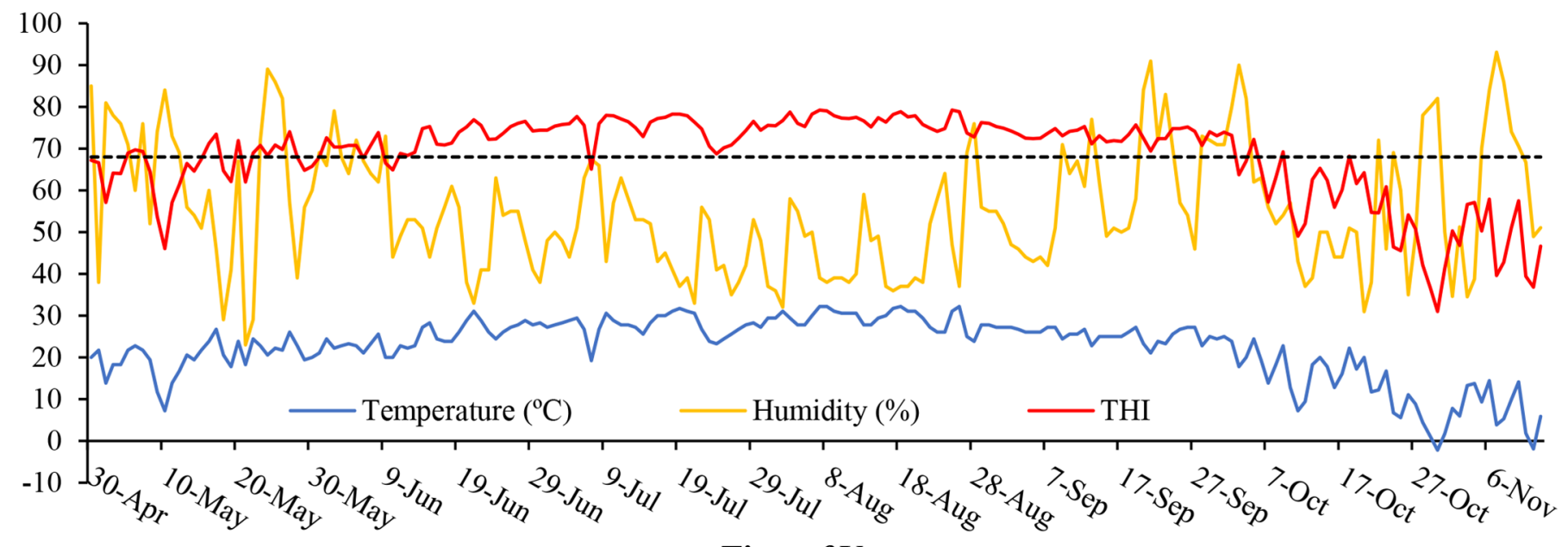

Time of Year

Figure 1. Daily mean environmental ambient temperature $\left({ }^{\circ} \mathrm{C}\right)$, relative humidity $(\%)$, and temperature-humidity index (THI) throughout the study from April 30 to November 13, 2019, in west Texas. Dotted lines indicate THI threshold for heat-stress conditions for dairy cows. 
mastitis from 26 to $18 \%$. Considering a significance level of $\alpha=0.05$ and a power of $80 \%$, at least 420 cows would have to be enrolled in each treatment group. Accounting for $10 \%$ attrition, 956 animals were enrolled in the study $(\mathrm{n}=462$ and $\mathrm{n}=494$ for control and ITMS group, respectively). With this sample size, we were able to detect a milk yield difference between the groups of $1.1 \mathrm{~kg} / \mathrm{d}$ with standard deviation of $6 \mathrm{~kg} / \mathrm{d}$, considering $\alpha=0.05$ and a power of $80 \%$. For blood analysis, based on significant differences detected by Nightingale et al. (2015) and Silva et al. (2020) with regard to the proportion of PMNL that could perform oxidative burst during the early postpartum period, we expected that the proportion of PMNL that could perform oxidative burst would be 8 percentage points greater in the ITMS group compared with cows in the control group. Considering a standard deviation of 15 and assuming $\alpha=0.05$ and a power of $80 \%$, at least 60 cows in each group would be needed.

\section{Inclusion Criteria, Treatment Allocation, Case Definitions, and Data Collection}

Dry cows were included in the study based on expected calving date (between July and September). A randomized clinical trial blocked by farm included a total of 923 multiparous cows (from 956 animals enrolled in the study, 33 of them were excluded due to loss to follow-up). At dry-off, cows were randomly allocated into 1 of 2 treatment groups as follows: ITMS or control. Randomization was completed in Excel 2019 (Microsoft Corp.) and imported into the farm's management software program as treatments $\mathrm{A}$ and B. Farm personnel were unaware of the coding and were blinded to treatment allocation. Cows that were randomly assigned to the ITMS group received $7 \mathrm{~mL}$ of subcutaneous injections of $15 \mathrm{mg} / \mathrm{mL} \mathrm{Cu}, 5 \mathrm{mg} /$ $\mathrm{mL} \mathrm{Se}, 60 \mathrm{mg} / \mathrm{mL} \mathrm{Zn}$, and $10 \mathrm{mg} / \mathrm{mL} \mathrm{Mn} \mathrm{(Multimin}$ 90, Multimin North America) at dry-off $(208 \pm 3 \mathrm{~d}$ of gestation), $260 \pm 3 \mathrm{~d}$ of gestation, and at $35 \pm 3$ DIM. Pregnant heifers were not enrolled in the study because ITMS was not beneficial to cows entering the lactating herd (Machado et a., 2013). The ITMS administration was performed by the research team.

Postpartum diseases were diagnosed and treated by trained farm personnel who were blinded to treatments. Metritis was defined as the presence of fetid, watery, red-brown uterine discharge (Sheldon et al., 2006). Clinical mastitis was defined by the diagnosis of abnormal changes in the udder or milk (Lago et al., 2011). Retained placenta (RP) was defined as the failure to release fetal membranes within $24 \mathrm{~h}$ of calving (Kelton et al., 1998). Stillbirth parturition was defined as the sum of stillbirth event + intrapartum fetal death + early neonatal death. Thus, the term stillbirth encompassed the death of a calf occurring just before, during, or within $48 \mathrm{~h}$ of parturition (Philipsson et al., 1979). Data regarding health traits, reproduction outcomes, milk yield, and survivability were extracted from Bovisynch (Dairy LLC) and DairyComp 305 (Valley Agricultural Software) databases on farms A and B, respectively, up to 300 DIM.

\section{Blood Collection and Analysis}

For a subset of 142 cows from farm A, blood samples were collected for differential blood cell count purposes, PMNL function, GPx and SOD concentrations, and circulating Hp. Blood samples were collected at enrollment and at $3 \pm 1,7 \pm 1,10 \pm 1$, and $35 \pm$ 3 DIM by puncture of the coccygeal vessels using a 10-mL Vacutainer tube without anticoagulant, a 10$\mathrm{mL}$ Vacutainer tube with lithium heparin, a 3-mL Vacutainer tube with potassium EDTA, and a 20-gauge $\times$ 2.54-cm Vacutainer needle (Becton, Dickinson and Co.). After collection, the heparinized blood was stored in an ice chest with no ice at ambient temperature to preserve their phagocytic and oxidative burst capacity (Sellers et al., 2013). The EDTA and coagulated blood samples were immediately placed on ice. Samples were analyzed or processed within $3 \mathrm{~h}$ after collection. The blood samples without anticoagulants were centrifuged at $2,000 \times g$ for $15 \mathrm{~min}$ at $4^{\circ} \mathrm{C}$ for serum separation, and frozen at $-80^{\circ} \mathrm{C}$. The heparinized and EDTA blood samples were processed in the same day of collection for measures of differential blood cell count and ex vivo PMNL responses.

Leukocyte count and differentials were performed using a hematology analyzer (Idexx Procyte DX), and the variables of interest were total leukocytes, monocytes, neutrophils, lymphocytes, and neutrophil-to-lymphocyte ratio. Flow cytometry was used to determine the phagocytosis and oxidative burst capacity of PMNL and the quantification of their adhesion molecule L-selectin (CD62 L). Both procedures were performed as previously described by Hulbert et al., (2011) with minor protocol modifications. To measure the phagocytic and oxidative burst capacity, $100 \mu \mathrm{L}$ of heparinized whole blood were incubated for $15 \mathrm{~min}$ in an ice bath. After this initial incubation, $20 \mu \mathrm{L}$ of a $100 \mu \mathrm{M}$ solution of dihydrorhodamine (Invitrogen) and $20 \mu \mathrm{L}$ of a $10^{9} \mathrm{cfu} /$ $\mathrm{mL}$ propidium iodide-labeled E. coli suspension were added to the blood and then incubated in a $38.5^{\circ} \mathrm{C}$ water bath for $10 \mathrm{~min}$ (negative controls were incubated in an ice bath for $10 \mathrm{~min}$ ). Then, samples were immediately placed on an ice bath for $5 \mathrm{~min}$, and erythrocytes were hypotonically lysed and washed with PBS. Dual-color flow cytometry was performed using an Attune flow 
cytometer (Life Technologies/Thermo Fisher Scientific Inc.). The PMNL population was gated using forward and side scatter plots. The mean fluorescence intensity and proportion of PMNL that performed phagocytosis and oxidative burst were acquired using the optical filters BL3 (excited by a $488-n m$ laser on a $695 / 40$ filter) and BL1 (excited by a $488-n m$ laser on a $530 / 30$ filter), respectively. Negative controls were used to determine negative and positive signals on the BL1 by BL3 scatterplot used to assess PMNL that performed phagocytosis and oxidative burst. To determine the expression of the adhesion molecule L-selectin, $50 \mu \mathrm{L}$ of EDTA blood samples were mixed with $50 \mu \mathrm{L}$ of PBS containing $1 \mu \mathrm{g}$ of a monoclonal antibody mouse IgG1-isotype (catalog number: BOV2046, clone: BAQ92A; Veterinary Microbiology and Pathology Monoclonal Antibody Center). After a 1-h incubation in an ice bath, erythrocytes were hypotonically lysed. After centrifugation $(1,200 \times g$ for 5 min at $4^{\circ} \mathrm{C}$ ), the leukocyte pellet was resuspended in $50 \mu \mathrm{L}$ of fluorescein-labeled secondary antibody at a 1:400 dilution $\left[\mathrm{F}\left(\mathrm{ab}^{\prime}\right) 2\right.$ anti-mouse IgG:FITC; AbD Serotec] and incubated for $1 \mathrm{~h}$ in an ice bath. After a PBS wash, samples were analyzed using single-color flow cytometry. The PMNL population was gated as previously described, and the mean fluorescence intensity for L-selectin was gathered using BL-1. An unconjugated IgG1 isotype control was used to determine minimal nonspecific binding of the primary antibody used to determine CD62L (L-selectin) expression in bovine whole blood. The use of $\mathrm{F}\left(\mathrm{ab} \mathrm{b}^{\prime}\right) 2$ secondary conjugates and the use of secondary only controls confirmed minimal nonspecific binding. Data were analyzed using Attune $\mathrm{N} \times \mathrm{T}$ cytometric software, version 3.1.2 (Life Technologies/Thermo Fisher Scientific Inc.).

Commercial kits (Cayman Chemical) were used to assess the following serum antioxidant enzymes: GPx (\#703102) and SOD (\#706002). Serum Hp concentration was determined using a colorimetric assay via quantification of the Hp-hemoglobin complex by the estimation of differences in peroxidase activity (Makimura and Suzuki, 1982). Assays were performed in 16 $\times 100$ borosilicate tubes. Briefly, $5 \mu \mathrm{L}$ of serum sample or deionized water (blank) was added to $7.5 \mathrm{~mL}$ of a solution containing $0.6 \mathrm{~g} / \mathrm{L}$ o-dianisidine, $13.8 \mathrm{~g} / \mathrm{L}$ sodium phosphate monobasic, and $0.5 \mathrm{~g} / \mathrm{L}$ EDTA $(\mathrm{pH}=$ 4.1). Immediately, $25 \mu \mathrm{L}$ of $0.3 \mathrm{~g} / \mathrm{L}$ bovine hemoglobin solution was added to each assay, followed by a water bath incubation at $37^{\circ} \mathrm{C}$ for $45 \mathrm{~min}$. After incubation, $100 \mu \mathrm{L}$ of freshly prepared $156 \mathrm{~m} M$ hydrogen peroxidase solution was added to each assay. Samples were incubated at room temperature for $60 \mathrm{~min}$. Then, $200 \mu \mathrm{L}$ of each assay was transferred to a 96-well polystyrene flat-bottom microplate. Optical density at $450 \mathrm{~nm}$ was measured on the Epoch2 Microplate Spectrophotome- ter (BioTek Instruments Inc.). Finally, the final optical density of each assay was subtracted by the blank assay values. Optical density data were converted to concentration units $(\mu \mathrm{g} / \mathrm{mL})$ using standard curves generated by serial dilutions of a sample of known concentration determined by a commercially available ELISA kit following the manufacturer's instructions (Life Technologies) as previously described (Cooke and Arthington, 2013). The intra and interassay coefficient of variation for serum Hp were $1.8 \%$ and $5.9 \%$, respectively.

\section{Statistical Analysis}

All statistical analyses were performed in SAS version 9.4 (SAS Institute Inc.). Descriptive statistics analysis was undertaken using the FREQ procedure. The odds of metritis, clinical mastitis, RP, stillbirth, and pregnancy per AI $(\mathbf{P} / \mathbf{A I})$ at first service was assessed by fitting the data using the GLIMMIX procedure. The effect of treatment on reproduction and survival was analyzed by Cox's proportional hazard using the PHREG procedure. The proportional hazards assumption was tested visually through plots of the scaled Schoenfeld residuals using the model as a function of time. For analysis of reproduction, cows were right-censored if not diagnosed pregnant before culling, death, or the end of the datacollection period. For all models described above, the variables offered included treatment, parity $(2,>2)$, twins, and previous days of gestation. The independent variables and their respective interactions were kept when $P<0.10$. The models included the fixed effect of treatment, which was forced into all models, and farms, which were included as random effect. Adjustments for multiple comparison were not included for the logistic regression and Cox's proportional hazard models because the only variable of interest was treatment, and the other independent variables retained in the model were for controlling for confounding purposes. To illustrate the median calving-to-conception interval, and the median time to culling or death for each treatment group, Kaplan-Meier survival analysis was performed using MedCalc; the Logrank test was used to compute $P$-values.

The effect of ITMS on monthly milk yield during the first 180 DIM was evaluated through a repeated measures model fitted by multiple mixed linear models using the MIXED procedure. The model included the fixed effects of treatment, month of lactation, parity $(2$, $>2$ ), twins, and previous days carried calf. The independent variables and their respective interactions were kept when $P<0.10$. The farm variable was included as a random effect. The normality of the residuals was analyzed with normal probability and box plots visualization. To account appropriately for within-cow 
Table 2. Descriptive statistics of treatment groups ${ }^{1}$

\begin{tabular}{|c|c|c|}
\hline Item & Control & ITMS \\
\hline \multicolumn{3}{|l|}{ Farm A } \\
\hline Total number of enrolled animals (\%) & $253(50)$ & $252(50)$ \\
\hline Enrolled animals on parity $2(\%)$ & $81(48)$ & $87(52)$ \\
\hline Enrolled animals on parity >2 (\%) & $172(51)$ & $165(49)$ \\
\hline Average days of gestation at enrollment $( \pm \mathrm{SE})$ & $207.8(4.8)$ & $208.2(4.8)$ \\
\hline \multicolumn{3}{|l|}{ Subset of animals for blood evaluation } \\
\hline Total number of enrolled animals (\%) & $74(52)$ & $68(48)$ \\
\hline Enrolled animals on parity $2(\%)$ & $26(55)$ & $21(45)$ \\
\hline Enrolled animals on parity > $2(\%)$ & $48(51)$ & $47(49)$ \\
\hline Average days of gestation at enrollment $( \pm \mathrm{SE})$ & $208.3(1.6)$ & $208.1(2.0)$ \\
\hline \multicolumn{3}{|l|}{ Farm B } \\
\hline Total number of enrolled animals (\%) & $196(47)$ & $222(53)$ \\
\hline Enrolled animals on parity $2(\%)$ & $92(45)$ & $114(55)$ \\
\hline Enrolled animals on parity $>2(\%)$ & $104(49)$ & $108(51)$ \\
\hline Average days of gestation at enrollment $( \pm \mathrm{SE})$ & $209.6(5.2)$ & $209.2(5.2)$ \\
\hline Total enrolled animals on farms A and B (\%) & $449(49)$ & $474(51)$ \\
\hline Enrolled animals on parity $2(\%)$ & $173(46)$ & $201(54)$ \\
\hline Enrolled animals on parity $>2(\%)$ & $276(50)$ & $273(50)$ \\
\hline
\end{tabular}

${ }^{1}$ Control cows received no trace mineral injection; ITMS cows received 7-mL subcutaneous injections of $15 \mathrm{mg} /$ $\mathrm{mL} \mathrm{Cu}, 5 \mathrm{mg} / \mathrm{mL} \mathrm{Se}, 60 \mathrm{mg} / \mathrm{mL} \mathrm{Zn}$, and $10 \mathrm{mg} / \mathrm{mL} \mathrm{Mn} \mathrm{(Multimin} \mathrm{90,} \mathrm{Multimin} \mathrm{North} \mathrm{America)} \mathrm{at} \mathrm{dry-off}$ (208 $\pm 3 \mathrm{~d}$ of gestation), $260 \pm 3 \mathrm{~d}$ of gestation, and at $35 \pm 3 \mathrm{DIM}$.

correlation, the error term was modeled by a compound symmetry covariance structure due to its smallest Bayesian information criterion value.

To evaluate the effect of ITMS on leukocyte counts, PMNL phagocytosis and oxidative burst activity, SOD, GPx, and Hp throughout the 5 blood collection days (enrollment, 3, 7, 10, and $35 \mathrm{~d}$ relative to calving), repeat measures models were fitted by multiple mixed linear models using the MIXED procedure. The experimental unit was the cow. The normality of the residuals was analyzed with normal probability and box plots visualization. To account appropriately for withincow residues correlation, a spatial (power) covariance structure (SP[POW]) was applied for all models. This variance-covariance structure is indicated for unequally spaced data collection and assumes correlations decline as a function of time. For multivariate models above, independent variables and their respective interactions were kept when $P<0.10$. The effect of treatment, time, and their interaction were forced into all statistical models even in the absence of statistical significance. The SLICE option using a Bonferroni multiple comparison adjustment was used to explore interactions between treatment and time whenever the $F$-test was significant. Days of gestation at enrollment, parity (2, $>2$ ), and the value of the dependent variable assessed at enrollment were offered to all models as a covariate to control confounding effects. For all the analyses, differences detected at $P \leq 0.05$ were considered significant, and differences at $0.05<P<0.10$ were considered a tendency toward statistical significance.

\section{RESULTS}

\section{Descriptive Statistics}

A total of 956 animals were enrolled in the study. From these, 33 cows were excluded due to loss to follow-up, with 24 cows being from farm A (control group $=11$ and ITMS $=13$ ) and 9 cows being from farm B (control group $=2$ and ITMS group $=7$ ). A total of 923 cows from the initial 956 remained in the study. Descriptive statistics regarding the number of animals enrolled in parity 2 and $>2$ and average gestation length (days) at enrollment are presented in Table 2.

\section{Effect of ITMS on Health, Reproductive Performance, Milk Yield, and Culling}

The effect of treatment on health and P/AI at first service is presented in Table 3. Briefly, ITMS-treated cows tended to have lower incidence of metritis compared with control group [odds ratio $(\mathbf{O R})=0.68,95 \%$ $\mathrm{CI}=0.4-1.0, P=0.051]$. Additionally, administration of ITMS tended to reduce the incidence of stillbirth compared with cows in control group $(\mathrm{OR}=0.41,95 \%$ $\mathrm{CI}=0.17-1.01, P=0.052)$. However, supplementing cows with injectable trace minerals did not improve the odds of mastitis $(P=0.379)$ and $\mathrm{RP}(P=0.657)$ compared with unsupplemented cows.

Injectable trace mineral supplementation did not affect reproductive performance. The treatment did not improve $\mathrm{P} / \mathrm{AI}$ at first service $(\mathrm{OR}=1.03,95 \% \mathrm{CI}=$ 
Table 3. Effect of treatment on incidence (\%) of peripartum diseases and first-service conception

\begin{tabular}{lcccc}
\hline & \multicolumn{2}{c}{ Treatment $^{1}$} & & \\
\cline { 2 - 3 } Item & Control (\%) & ITMS (\%) & & Odds ratio \\
\cline { 2 - 3 } & & & & \\
Metritis & 12.6 & 8.6 & $0.63(0.40-1.0)$ & \\
Mastitis & 30.4 & 32.0 & $1.14(0.85-1.53)$ & 0.051 \\
Retained placenta & 8.7 & 7.7 & $0.89(0.54-1.47)$ & 0.379 \\
Stillbirth & 3.7 & 1.5 & $0.41(0.17-1.01)$ & 0.052 \\
First-service conception & 35.4 & 36.0 & $1.03(0.76-1.39)$ & 0.874 \\
\hline
\end{tabular}

${ }^{1}$ Control cows received no trace mineral injection; ITMS cows received 7 -mL subcutaneous injections of $15 \mathrm{mg} /$ $\mathrm{mL} \mathrm{Cu}, 5 \mathrm{mg} / \mathrm{mL} \mathrm{Se}, 60 \mathrm{mg} / \mathrm{mL} \mathrm{Zn}$, and $10 \mathrm{mg} / \mathrm{mL} \mathrm{Mn} \mathrm{(Multimin} \mathrm{90,} \mathrm{Multimin} \mathrm{North} \mathrm{America)} \mathrm{at} \mathrm{dry-off}$ (208 $\pm 3 \mathrm{~d}$ of gestation), $260 \pm 3 \mathrm{~d}$ of gestation, and at $35 \pm 3$ DIM.

$0.76-1.39, P=0.874)$ or hazard of pregnancy up to 150 DIM compared with control cows [hazard ratio $(\mathbf{H R})=$ $0.99,95 \% \mathrm{CI}=0.86-1.14, P=0.901]$. Additionally, no improvements in milk yield and culling were observed. The average milk yield during the first 6 mo of lactation for cows enrolled in control and ITMS group was $43.9 \mathrm{~kg} / \mathrm{d}$ and $43.4 \mathrm{~kg} / \mathrm{d}$, respectively $(P=0.177)$, and there was no interaction between treatment and month of lactation $(P=0.925)$. Furthermore, the hazard of culling up to 300 DIM was similar between the groups $(\mathrm{HR}=1.25,95 \% \mathrm{CI}=0.96-1.65, P=0.103)$. The survival curves for time-to-pregnancy and days to culling or death by treatment group is presented in Figure 2.

\section{Effect of ITMS on Hematology, PMNL Function, Antioxidant Enzymes, and $\mathrm{Hp}$}

The effect of ITMS on total leukocyte, monocyte, neutrophil, and lymphocyte counts, and neutrophilto-lymphocytes ratio are presented in Table 4. The ITMS treatment did not influence the total leukocytes, neutrophil, and lymphocyte counts during the study. However, neutrophil-to-lymphocyte ratio was greater for ITMS-treated cows in comparison to control cows throughout the study $(P=0.039)$. Additionally, ITMS did not influence the GPx, SOD, and Hp concentrations after calving $(P=0.966, P=0.320, P=0.210$ for GPx, SOD, and Hp, respectively; Table 4).

The ITMS treatment improved the PMNL function during the postpartum period due to increased proportion of PMNL that performed phagocytosis $(P=0.005)$ and oxidative burst $(P=0.001)$ and tended to increase the intensity of oxidative burst $(P=0.051$; Figure $3 \mathrm{~A}$, $\mathrm{B}, \mathrm{D})$. Additionally, the expression of L-selectin on PMNL surface was decreased in ITMS cows $(P=0.035$; Figure 3E).

\section{DISCUSSION}

In this study, ITMS-treated cows undergoing the transition period in THI $>68$ had improved PMNL function early postpartum. Accordingly, a reduction in the incidence of diseases was expected for supplemented cows in comparison to control cows. Nevertheless, only a numerical reduction in metritis and stillbirth incidence was detected, and no effect was observed of ITMS on the incidence of RP and mastitis. Machado et al. (2013) reported that ITMS improved udder health by decreasing the odds of clinical mastitis and reducing SCC linear scores throughout the first 6 mo of lactation; herein, we reported that udder health was not affected by ITMS because a reduction in clinical mastitis incidence was not observed. In the present study, we did not evaluate the effect of ITMS on SCC linear scores because of this information was not available in the farms' databases.

Although previous findings demonstrated that ITMS reduced uterine diseases, merely a tendency was reported herein. Machado et al. (2012) reported that ITMS reduced the presence of putative intrauterine pathogens in dairy cows $35 \mathrm{~d}$ after calving. Further, Machado et al. (2013) reported a lower incidence of clinical endometritis for cows that received ITMS according to the protocol performed in the present study. We also reported that ITMS numerically reduced the incidence of stillbirth, which has also been previously observed (Machado et al., 2013). Metritis and stillbirth parturition have been associated with impaired milk yield, poor reproductive performance, and culling in dairy cows (Bicalho et al., 2007, 2008; Dubuc et al., 2011; Wittrock et al., 2011). Because we did not detect positive effects of ITMS on reducing the risks of metritis and stillbirth parturition, no difference was detected in performance and survivability between the treatment groups. Likewise, Machado et al. (2013) observed that ITMS did not influence milk yield, reproductive outcomes, and culling of dairy cows. Additionally, Springman et al. (2018) and Vanegas et al. (2004) reported no beneficial effect of ITMS on reproduction outcomes in beef heifers and dairy cows, respectively.

Herein, we observed that ITMS improved PMNL function in the early postpartum period. Immune dys- 
A
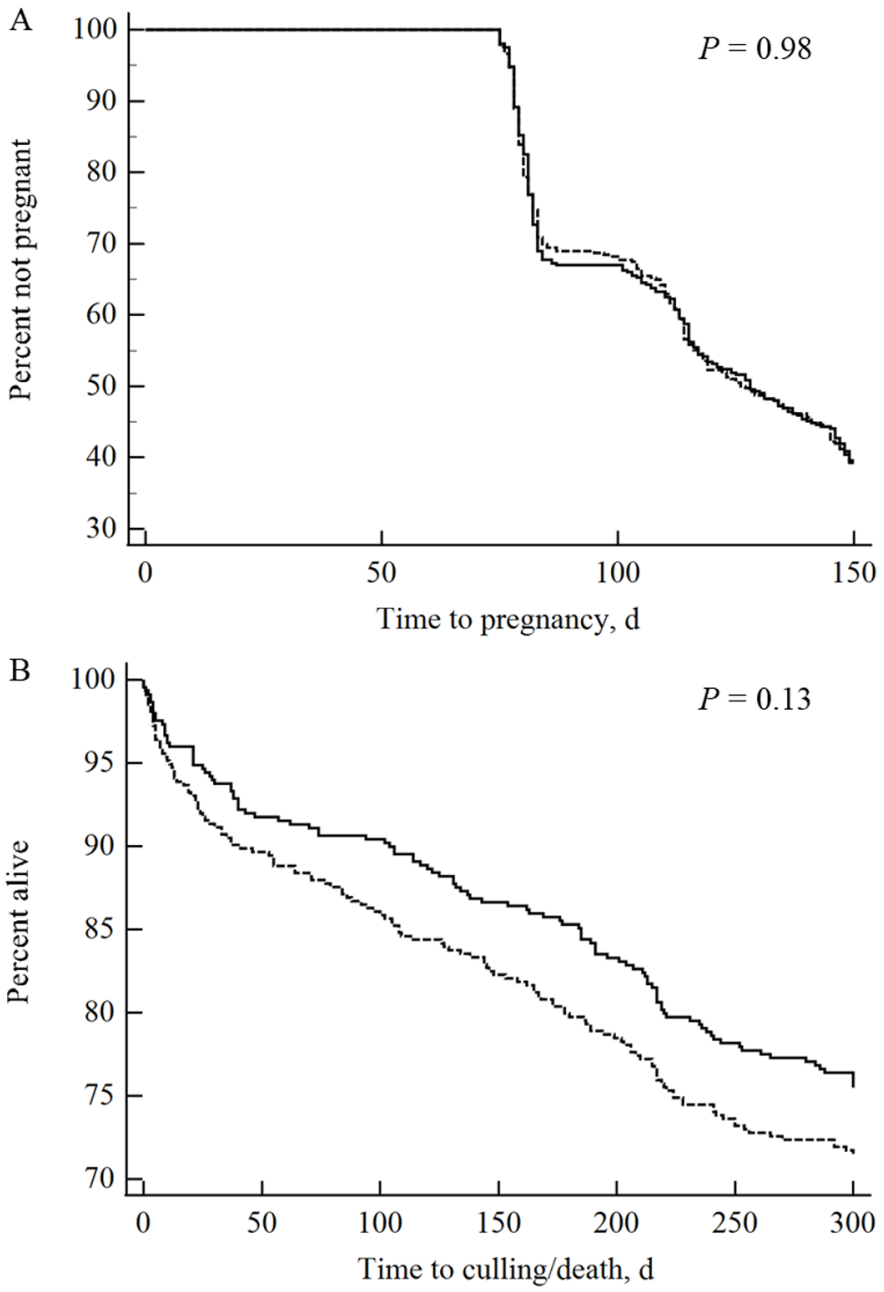

Figure 2. Kaplan-Meier survival analysis of (A) calving-to-conception interval and (B) days to culling or death for injectable trace mineral-supplemented (ITMS) cows [received $7 \mathrm{~mL}$ of subcutaneous injections of $15 \mathrm{mg} / \mathrm{mL} \mathrm{Cu}, 5 \mathrm{mg} / \mathrm{mL} \mathrm{Se}, 60 \mathrm{mg} / \mathrm{mL} \mathrm{Zn}$, and $10 \mathrm{mg} /$ mL Mn (Multimin 90, Multimin North America) at $208 \pm 3 \mathrm{~d}$ of gestation, $260 \pm 3 \mathrm{~d}$ of gestation, and at $35 \pm 3$ DIM; dashed line] and control cows (solid line). regulation during the postpartum period is thought to be one of the major causes of increased incidence of uterine and udder diseases in dairy cows (Kim et al., 2005; Hammon et al., 2006; Sordillo, 2013). However, in the present study, the greater proportions of PMNL performing phagocytosis and oxidative burst, coupled with improved oxidative burst intensity in ITMS-treated cows did not translate into improved health outcomes. Although Machado et al. (2014) reported that ITMS did not improve PMNL function at 10 DIM, others have observed that trace mineral supplementation improved immunity. Studies in beef and dairy cattle have demonstrated the benefit of using ITMS concurrently with bovine respiratory disease vaccines on humoral and cell-mediated immune responses (Palomares et al., 2016; Roberts et al., 2016; Bittar et al., 2018, 2020). Additionally, preweaning calves that received ITMS at $3 \mathrm{~d}$ of life had increased PMNL phagocytic activity at $14 \mathrm{~d}$ of life (Teixeira et al., 2014). The positive effect of trace mineral supplementation on PMNL activity may be linked to trace mineral action on intracellular enzymatic modulation, such as cytosolic superoxide dismutase ( $\mathrm{Cu}$ - and $\mathrm{Zn}$-dependent) and mitochondrial superoxide dismutase (Mn- and Zn-dependent; Suttle, 2010; Sordillo, 2016), but these variables were not evaluated herein, and more research is needed to test these hypotheses.

Additionally, the results of the current study suggested that trace mineral supplementation resulted in a more robust innate immune system in the early postpartum period. Initial steps in the recruitment process of PMNL to the infection sites involves rolling and attachment to the endothelium near the inflammation site. This process is dependent on the interaction between L-selectin protein adhesion receptors on the PMNL surface and its ligand on endothelial cells. Hence, we suggest that the earlier and greater neu-

Table 4. Effect of treatment on hematology, antioxidant enzymes, and haptoglobin (Hp)

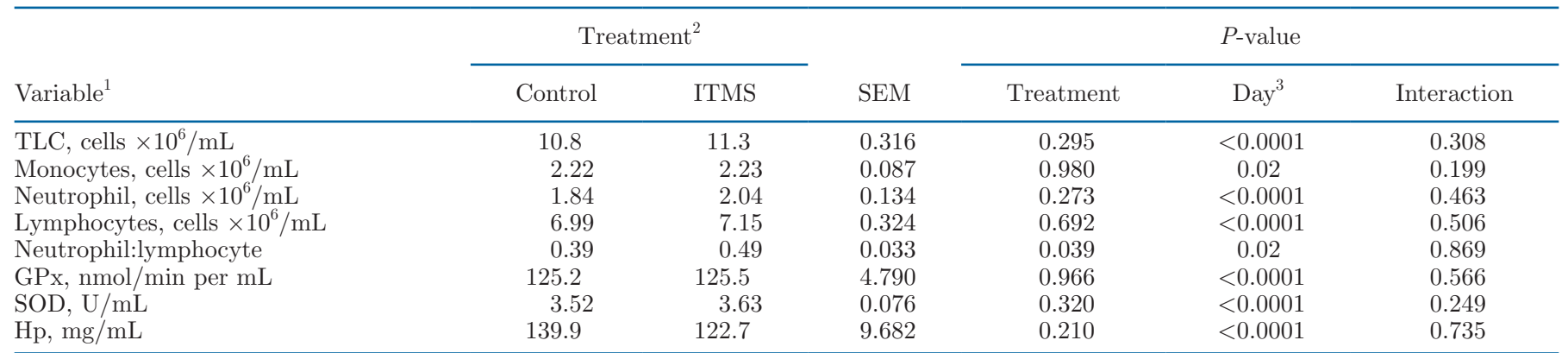

${ }^{1} \mathrm{TLC}=$ total leukocyte count; GPx $=$ glutathione peroxidase; SOD $=$ superoxide dismutase.

${ }^{2}$ Control cows $(\mathrm{n}=74)$ received no trace mineral injection; ITMS cows $(\mathrm{n}=68)$ received 7 - $\mathrm{mL}$ subcutaneous injections of $15 \mathrm{mg} / \mathrm{mL} \mathrm{Cu}, 5 \mathrm{mg} /$ $\mathrm{mL} \mathrm{Se}, 60 \mathrm{mg} / \mathrm{mL} \mathrm{Zn}$, and $10 \mathrm{mg} / \mathrm{mL}$ Mn (Multimin 90, Multimin North America) at dry-off (208 $\pm 3 \mathrm{~d}$ of gestation), $260 \pm 3 \mathrm{~d}$ of gestation, and at $35 \pm 3$ DIM.

${ }^{3}$ Days relative to calving $(-72,3,7,10,35 \mathrm{~d})$. 

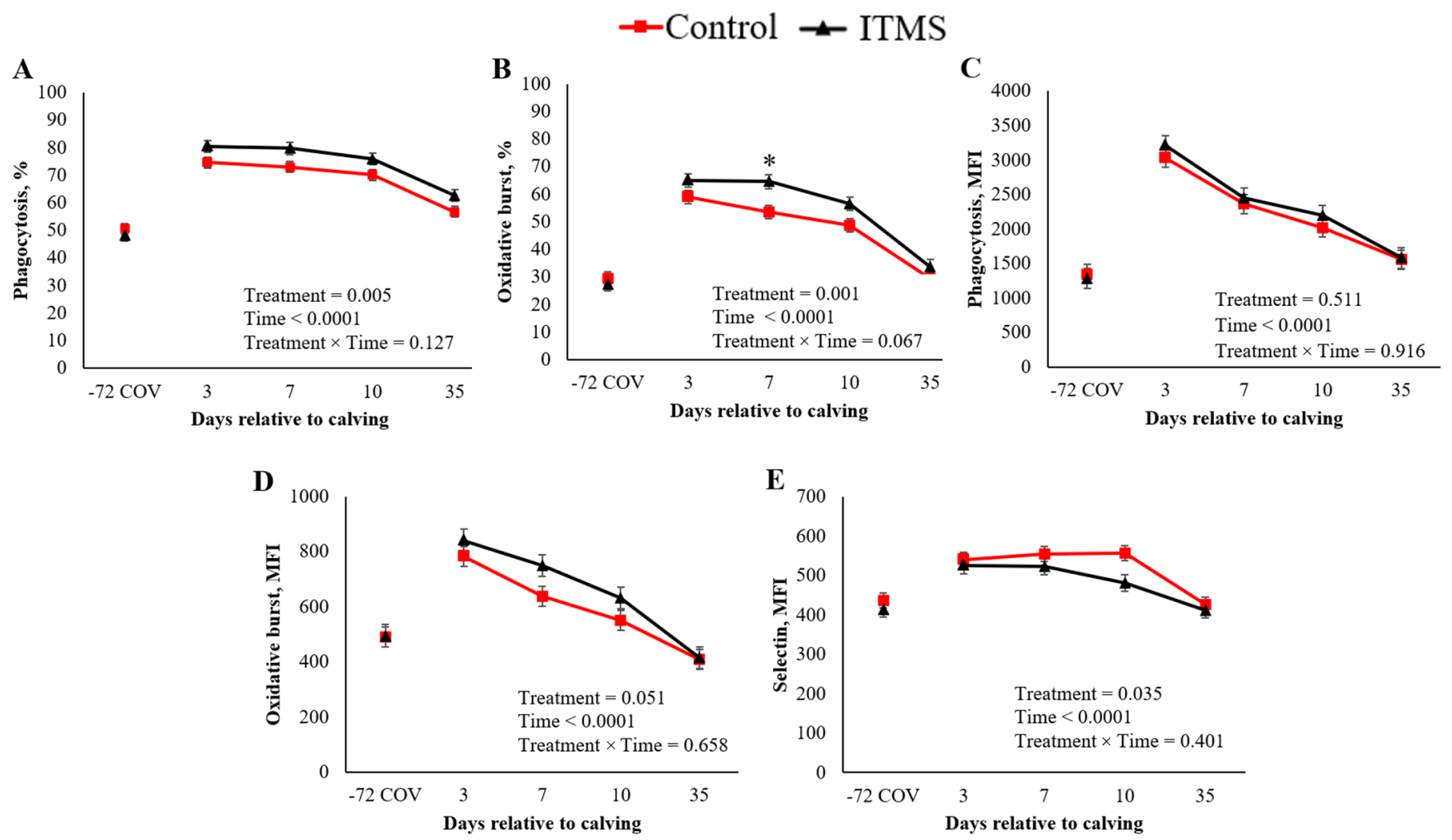

Figure 3. The effect of treatment on percentage of polymorphonuclear leukocytes (PMNL) that performed phagocytosis (panel A), percentage of PMNL that performed oxidative burst (panel B); phagocytosis mean fluorescence intensity (MFI; panel C), oxidative burst MFI (panel $\mathrm{D})$, and L-selectin MFI (panel E). Control cows $(\mathrm{n}=74)$ received no trace mineral injection; injectable trace mineral-supplemented ITMS cows $(\mathrm{n}=68)$ received $7-\mathrm{mL}$ subcutaneous injections of $15 \mathrm{mg} / \mathrm{mL} \mathrm{Cu}, 5 \mathrm{mg} / \mathrm{mL} \mathrm{Se}, 60 \mathrm{mg} / \mathrm{mL} \mathrm{Zn}$, and $10 \mathrm{mg} / \mathrm{mL} \mathrm{Mn} \mathrm{(Multimin} \mathrm{90,} \mathrm{Multimin}$ North America) at dry-off (208 $\pm 3 \mathrm{~d}$ of gestation), $260 \pm 3 \mathrm{~d}$ of gestation, and at $35 \pm 3$ DIM. COV = covariate (values at enrollment). Error bars represent SEM.*Indicates $P \leq 0.05$.

trophils activation detected in ITMS cows could have resulted in earlier regulation of inflammation, which led to a reduced expression of L-selectin on PMNL surface from ITMS-treated cows. The source of trace minerals fed to cattle seems to influence the expression of Lselectin. For instance, Jacometo et al. (2015) indicated that calves from dams fed organic trace minerals ( $\mathrm{Zn}$, $\mathrm{Cu}, \mathrm{Mn}$, and $\mathrm{Co}$ ) during the last $30 \mathrm{~d}$ of gestation had lower L-selectin expression compared with calves from dams fed trace minerals from inorganic sources. Greater neutrophil-to-lymphocyte ratio was observed among the ITMS cows. Generally, neutrophil-to-lymphocyte ratio has been associated with chronic and acute inflammatory processes due to margination, redistribution, and accelerated apoptosis of lymphocytes (Zahorec, 2001). In the context of the other results observed herein, greater neutrophil-to-lymphocyte ratio among ITMS cows could represent greater inflammatory potential throughout the first days postpartum, which could have contributed to greater capacity to eliminate the uterine pathogens. Guan et al. (2020) reported that there is a positive association between inflammatory cytokines and neutrophil-to-lymphocyte ratio during the development of acquired immunity, leading to improved responsiveness of the immune system against pathogens. Additionally, because PMNL from ITMS cows were more active in the postpartum period, it is possible that PMNL from these cows stayed in the bloodstream longer due to the reduced L-selectin expression detected herein, which could be another explanation for the altered neutrophil-to-lymphocyte ratio. On the other hand, an overly robust inflammatory response during the transition period may lead to extensive damage to host tissues (Sordillo, 2016). However, we did not detect any negative effect of greater inflammatory potential of ITMS cows on health, milk yield, reproductive performance, and survivability.

In the present study, the lack of effect of ITMS in stillbirth may be a result of the inefficacy of ITMS to increase the activity of the antioxidant enzymes GPx and SOD. We initially hypothesized that potential benefits of ITMS on reducing stillbirth could be due to improved overall antioxidant capacity in the last month of lactation (Machado et al., 2013, 2014). In sows, high 
total antioxidant capacity has been associated with a low incidence of stillbirth (Wang et al., 2019). Sciorsci et al. (2020) showed that blood ROS concentration undergoes an expressive increase from 180 to $210 \mathrm{~d}$ of pregnancy onwards. These ROS may compromise the physiology of the fetal-maternal unit, making it more susceptible to bacterial infection. Murray et al. (2008) reported that nutritional degenerative myopathy due to low uptake of Se and vitamin E was associated with myocardial necrosis found in stillborn fetuses. The authors explain that the Se-vitamin E complex, which increases GPx concentration, helps to protect the fetus and placenta against external ROS damage. However, it is important to highlight that we did not observe the effect of ITMS on GPx and SOD concentration and on stillbirth. Likewise, Bicalho et al. (2014) did not observe differences in serum SOD and GPx concentrations. On the other hand, Machado et al. (2014) detected higher blood SOD concentration in dairy cows during the transition period and subsequent lactation when supplemented with injectable trace minerals. Bernabucci et al. (2002) suggested that erythrocyte markers are a more appropriate and sensitive model to assess the oxidative status of moderate heat-stressed transition dairy cows than plasma markers. Further, Abuelo et al. (2013) considered that the concentration of anti- and pro-oxidants separately is not a good indicator of oxidative stress because it is the imbalance between them that defines the oxidative stress. Therefore, as we merely investigated the effect of ITMS on GPx and SOD activities of heat-stressed transition dairy cows, it is possible that we were not able to assess the real antioxidant capacity of the animals because trace minerals supplementation may act at other levels of the antioxidant network. In addition, as a limitation of this study, we did not assess any biological marker that could confirm the direct effect of elevated THI conditions on oxidative stress status of transition dairy cows.

The objectives of this study were to evaluate the effect of ITMS on the health, performance, postpartum immunity, and antioxidative status in dairy cows undergoing their transition period in an environment with THI $>68$. The meteorological analysis presented in Figure 1 demonstrates that THI was greater than 68 for most days when study cows were undergoing their transition period ( $3 \mathrm{wk}$ before and $3 \mathrm{wk}$ after calving). Additionally, all cows were housed in dry-lot pens during the dry period without fans and soaking lines, being more exposed to environmental changes in the weeks before calving. The THI has been widely used as an indicator of heat stress in dairy cows, and thus we believe that our study cows experienced heatstress conditions during the transition period. However, the findings presented herein should be interpreted with care because we did not collect the physiological parameters for assessing heat stress (e.g., rectal temperature and respiration rate). According to Hammami et al. (2013), there are limitations to the use of THI to characterize heat stress. For instance, THI is an empirical representation of heat stress that does not assume the individual response of the animals to different environmental stressors. Moreover, the absence of other environmental factors in the THI equation, such as solar radiation and wind speed, are other limitations to this measure. Another study limitation could be the misclassification of diseases when using farm records, although the randomization procedure minimizes different distribution of this phenomenon by treatment groups.

\section{CONCLUSIONS}

Injectable trace mineral supplement containing $\mathrm{Cu}$, Se, Zn, and Mn at dry-off (208 \pm 3 d of gestation), 260 $\pm 3 \mathrm{~d}$ of gestation, and at $35 \pm 3$ DIM did not improve health, milk yield, reproductive performance, survivability, and the concentration of serum GPx and SOD concentrations of dairy cows undergoing the transition period in THI $>68$. However, our findings suggest that ITMS improved innate immunity during the early postpartum period, but this improvement in innate immunity response did not lead to improved health, as we only observed numerical changes in the incidence of metritis and stillbirth.

\section{ACKNOWLEDGMENTS}

The authors thank the owners and staff of the participating farms for the use of their cows and facilities. This study was sponsored by Multimin North America (Fort Collins, CO), which did not have any input in the study design, data collection and analysis, interpretation of results, and manuscript preparation. The first author, THS, was supported by a scholarship from the São Paulo Research Foundation (FAPESP, São Paulo, Brazil; grant \# 2018/24602-3). The authors have stated any conflicts of interest.

\section{REFERENCES}

Abd El-Hack, M. E., K. Mahrose, M. Arif, M. T. Chaudhry, I. M. Saadeldin, M. Saeed, R. N. Soomro, I. H. R. Abbasi, and Z. U. Rehman.. 2017. Alleviating the environmental heat burden on laying hens by feeding on diets enriched with certain antioxidants (vitamin E and selenium) individually or combined. Environ. Sci Pollut. Res. Int. 24:10708-10717. https://doi.org/10.1007/s11356 $-017-8690-5$.

Abuelo, A., J. Hernández, J. L. Benedito, and C. Castillo.. 2013. Oxidative stress index (OSi) as a new tool to assess redox status 
in dairy cattle during the transition period. Animal 7:1374-1378. https://doi.org/10.1017/S1751731113000396.

Adin, G., A. Gelman, R. Solomon, I. Flamenbaum, M. Nikbachat, E. Yosef, A. Zenou, A. Shamay, Y. Feuermann, S. J. Mabjeesh, and J. Miron.. 2009. Effects of cooling dry cows under heat load conditions on mammary gland enzymatic activity, intake of food and water, and performance during the dry period and after parturition. Livest. Sci. 124:189-195. https://doi.org/10.1016/j.livsci 2009.01.014.

Alhidary, I. A., S. Shini, R. A. M. Al Jassim, A. M. Abudabos, and J. B. Gaughan.. 2015. Effects of selenium and vitamin E on performance, physiological response, and selenium balance in heat-stressed sheep. J. Anim. Sci. 93:576-588. https://doi.org/10 $.2527 /$ jas. 2014-8419.

AOAC International. 2000. Official Methods of Analysis - Animal Feed. 17th ed. AOAC International.

AOAC International. 2005. Official Methods of Analysis. 18th ed. AOAC International.

Bernabucci, U., B. Ronchi, N. Lacetera, and A. Nardone.. 2002. Markers of oxidative status in plasma and erythrocytes of transition dairy cows during hot season. J. Dairy Sci. 85:2173-2179. https://doi.org/10.3168/jds.S0022-0302(02)74296-3.

Bicalho, M. L. S., F. S. Lima, E. K. Ganda, C. Foditsch, E. B. S. Meira Jr., V. S. Machado, A. G. V. Teixeira, G. Oikonomou, R. O. Gilbert, and R. C. Bicalho. 2014. Effect of trace mineral supplementation on selected minerals, energy metabolites, oxidative stress, and immune parameters and its association with uterine diseases in dairy cattle. J. Dairy Sci. 97:4281-4295. https://doi .org/10.3168/jds.2013-7832.

Bicalho, R. C., K. N. Galvão, S. H. Cheong, R. O. Gilbert, L. D. Warnick, and C. L. Guard.. 2007. Effect of stillbirths on dam survival and reproduction performance in Holstein dairy cows. J. Dairy Sci. 90:2797-2803. https://doi.org/10.3168/jds.2006-504.

Bicalho, R. C., K. N. Galvão, L. D. Warnick, and C. L. Guard.. 2008. Stillbirth parturition reduces milk production in Holstein cows. Prev. Vet. Med. 84:112-120. https://doi.org/10.1016/j.prevetmed 2007.11.006

Bittar, J. H. J., D. J. Hurley, A. R. Woolums, N. A. Norton, C. E. Barber, F. Moliere, L. J. Havenga, and R. A. Palomares.. 2018. Effects of injectable trace minerals on the immune response to Mannheimia haemolytica and Pasteurella multocida following vaccination of dairy calves with a commercial attenuated-live bacterin vaccine. Prof. Anim. Sci. 34:59-66. https://doi.org/10.15232/pas .2017-01695

Bittar, J. H. J., R. A. Palomares, D. J. Hurley, A. Hoyos-jaramillo, A. Rodriguez, A. Stoskute, B. Hamrick, N. Norton, M. Adkins, J. T. Saliki, S. Sanchez, and K. Lauber.. 2020. Immune response and onset of protection from Bovine viral diarrhea virus 2 infection induced by modified-live virus vaccination concurrent with injectable trace minerals administration in newly received beef calves. Vet. Immunol. Immunopathol. 225:110055. https://doi .org/10.1016/j.vetimm.2020.110055.

Cooke, R. F., and J. D. Arthington.. 2013. Concentrations of haptoglobin in bovine plasma determined by ELISA or a colorimetric method based on peroxidase activity. J. Anim. Physiol. Anim. Nutr. (Berl.) 97:531-536. https://doi.org/10.1111/j.1439-0396 2012.01298.x.

Dikmen, S., and P. J. Hansen.. 2009. Is the temperature-humidity index the best indicator of heat stress in lactating dairy cows in a subtropical environment? J. Dairy Sci. 92:109-116. https://doi .org/10.3168/jds.2008-1370.

do Amaral, B. C., E. E. Connor, S. Tao, M. J. Hayen, J. W. Bubolz, and G. E. Dahl.. 2011. Heat stress abatement during the dry period influences metabolic gene expression and improves immune status in the transition period of dairy cows. J. Dairy Sci. 94:8696. https://doi.org/10.3168/jds.2009-3004.

Dubuc, J., T. F. Duffield, K. E. Leslie, J. S. Walton, and S. J. LeBlanc.. 2011. Effects of postpartum uterine diseases on milk production and culling in dairy cows. J. Dairy Sci. 94:1339-1346. https:/ /doi.org/10.3168/jds.2010-3758.
Gernand, E., S. König, and C. Kipp.. 2019. Influence of on-farm measurements for heat stress indicators on dairy cow productivity, female fertility, and health. J. Dairy Sci. 102:6660-6671. https:// doi.org/10.3168/jds.2018-16011.

Guan, R. W., D. M. Wang, B. B. Wang, L. Y. Jiang, and J. X. Liu.. 2020. Prognostic potential of pre-partum blood biochemical and immune variables for postpartum mastitis risk in dairy cows. BMC Vet. Res. 16:136. https://doi.org/10.1186/s12917-020-02314-6.

Hammami, H., J. Bormann, N. M'hamdi, H. H. Montaldo, and N. Gengler.. 2013. Evaluation of heat stress effects on production traits and somatic cell score of Holsteins in a temperate environment. J. Dairy Sci. 96:1844-1855. https://doi.org/10.3168/jds 2012-5947.

Hammon, D. S., I. M. Evjen, T. R. Dhiman, J. P. Goff, and J. L. Walters.. 2006. Neutrophil function and energy status in Holstein cows with uterine health disorders. Vet. Immunol. Immunopathol. 113:21-29. https://doi.org/10.1016/j.vetimm.2006.03.022.

Hulbert, L. E., C. J. Cobb, J. A. Carroll, and M. A. Ballou.. 2011. Effects of changing milk replacer feedings from twice to once daily on Holstein calf innate immune responses before and after weaning. J. Dairy Sci. 94:2557-2565. https://doi.org/10.3168/jds.2010 -3980 .

Jacometo, C. B., J. S. Osorio, M. Socha, M. N. Corrêa, F. PiccioliCappelli, E. Trevisi, and J. J. Loor.. 2015. Maternal consumption of organic trace minerals alters calf systemic and neutrophil mRNA and microRNA indicators of inflammation and oxidative stress. J. Dairy Sci. 98:7717-7729. https://doi.org/10.3168/jds .2015-9359.

Kelton, D. F., K. D. Lissemore, and R. E. Martin.. 1998. Recommendations for recording and calculating the incidence of selected clinical diseases of dairy cattle. J. Dairy Sci. 81:2502-2509. https: //doi.org/10.3168/jds.S0022-0302(98)70142-0.

Kim, I. H., K. J. Na, and M. P. Yang.. 2005. Immune responses during the peripartum period in dairy cows with postpartum endometritis. J. Reprod. Dev. 51:757-764. https://doi.org/10.1262/ jrd.17036.

Lacetera, N. 2012. Effect of Environment on Immune Functions. 1st ed. R. J. Collier and J. L. Collier, ed. Wiley.

Lacetera, N., U. Bernabucci, D. Scalia, B. Ronchi, G. Kuzminsky, and A. Nardone.. 2005. Lymphocyte functions in dairy cows in hot environment. Int. J. Biometeorol. 50:105-110. https://doi.org/ 10.1007/s00484-005-0273-3.

Lago, A., S. M. Godden, R. Bey, P. L. Ruegg, and K. Leslie.. 2011. The selective treatment of clinical mastitis based on on-farm culture results: I. Effects on antibiotic use, milk withholding time, and short-term clinical and bacteriological outcomes. J. Dairy Sci. 94:4441-4456. https://doi.org/10.3168/jds.2010-4046.

LeBlanc, S. J. 2020. Review: Relationships between metabolism and neutrophil function in dairy cows in the peripartum period. Animal 14:s44-s54. https://doi.org/10.1017/S1751731119003227.

Lecchi, C., N. Rota, A. Vitali, F. Ceciliani, and N. Lacetera.. 2016. In vitro assessment of the effects of temperature on phagocytosis, reactive oxygen species production and apoptosis in bovine polymorphonuclear cells. Vet. Immunol. Immunopathol. 182:89-94. https://doi.org/10.1016/j.vetimm.2016.10.007.

Machado, V. S., M. L. Bicalho, R. V. Pereira, L. S. Caixeta, W. A Knauer, G. Oikonomou, R. O. Gilbert, and R. C. Bicalho. 2013. Effect of an injectable trace mineral supplement containing selenium, copper, zinc, and manganese on the health and production of lactating Holstein cows. Vet. J. 197:451-456. https://doi.org/10 $.1016 / j . t v j 1.2013 .02 .022$.

Machado, V. S., G. Oikonomou, M. L. S. Bicalho, W. A. Knauer, R. Gilbert, and R. C. Bicalho.. 2012. Investigation of postpartum dairy cows' uterine microbial diversity using metagenomic pyrosequencing of the 16S rRNA gene. Vet. Microbiol. 159:460-469. https://doi.org/10.1016/j.vetmic.2012.04.033.

Machado, V. S., G. Oikonomou, S. F. Lima, M. L. S. Bicalho, C. Kacar, C. Foditsch, M. J. Felippe, R. O. Gilbert, and R. C. Bicalho.. 2014. The effect of injectable trace minerals (selenium, copper, zinc, and manganese) on peripheral blood leukocyte activ- 
ity and serum superoxide dismutase activity of lactating Holstein cows. Vet. J. 200:299-304. https://doi.org/10.1016/j.tvjl.2014.02 .026 .

Makimura, S., and N. Suzuki.. 1982. Quantitative determination of bovine serum Haptoglobin and its elevation in some inflammatory diseases. Nippon Juigaku Zasshi 44:15-21. https://doi.org/10 $.1292 /$ jvms1939.44.15.

Murray, R. D., A. J. Williams, and I. M. Sheldon.. 2008. Field investigation of perinatal mortality in Friesian cattle associated with myocardial degeneration and necrosis. Reprod. Domest. Anim. 43:339-345. https://doi.org/10.1111/j.1439-0531.2007.00911.x.

Nightingale, C. R., M. D. Sellers, and M. A. Ballou.. 2015. Elevated plasma haptoglobin concentrations following parturition are associated with elevated leukocyte responses and decreased subsequent reproductive efficiency in multiparous Holstein dairy cows. Vet. Immunol. Immunopathol. 164:16-23. https://doi.org/10.1016/j .vetimm.2014.12.016.

NRC. 1971. Nutrient Requirements of Dairy Cattle. 4th ed. National Academies Press.

NRC. 2001. Nutrient Requirements of Dairy Cattle. 7th rev. ed. National Academies Press.

Overton, T. R., and T. Yasui.. 2014. Practical applications of trace minerals for dairy cattle. J. Anim. Sci. 92:416-426. https://doi . org $/ 10.2527 /$ jas.2013-7145.

Palomares, R. A., D. J. Hurley, J. H. J. Bittar, J. T. Saliki, A. R. Woolums, F. Moliere, L. J. Havenga, N. A. Norton, S. J. Clifton, A. B. Sigmund, C. E. Barber, M. L. Berger, M. J. Clark, and M. A. Fratto.. 2016. Effects of injectable trace minerals on humoral and cell-mediated immune responses to Bovine viral diarrhea virus, Bovine herpes virus 1 and Bovine respiratory syncytial virus following administration of a modified-live virus vaccine in dairy calves. Vet. Immunol. Immunopathol.1 78:88-98. https://doi.org/ 10.1016/j.vetimm.2016.07.003.

Philipsson, J., J. L. Foulley, J. Lederer, T. Liboriussen, and A. Osinga.. 1979. Sire evaluation standards and breeding strategies for limiting dystocia and stillbirth. Report of an E.E.C./E.A.A.P. working group. Livest. Prod. Sci. 6:111-127. https://doi.org/10 .1016/0301-6226(79)90013-7.

Rajkumar, U., A. Vinoth, E. P. K. Reddy, M. Shanmugam, and S. V. R. Rao. 2018. Effect of supplemental trace minerals on $\mathrm{Hsp}_{\mathrm{s}} \mathrm{70}$ $m R N A$ expression in commercial broiler chicken. Anim. Biotechnol. 29:20-25. https://doi.org/10.1080/10495398.2017.1287712.

Rhoads, R. P., L. H. Baumgard, J. K. Suagee, and S. R. Sanders. 2013. Nutritional interventions to alleviate the negative consequences of heat stress. Adv. Nutr. 4:267-276. https://doi.org/10 $.3945 /$ an.112.003376.

Roberts, S. L., N. D. May, C. L. Brauer, W. W. Gentry, C. P. Weiss, J. S. Jennings, and J. T. Richeson.. 2016. Effect of injectable trace mineral administration on health, performance, and vaccine response of newly received feedlot cattle. Prof. Anim. Sci. 32:842848. https://doi.org/10.15232/pas.2016-01543.

Safa, S., S. Kargar, G. A. Moghaddam, M. G. Ciliberti, and M. Caroprese.. 2019. Heat stress abatement during the postpartum period: Effects on whole lactation milk yield, indicators of metabolic status, inflammatory cytokines, and biomarkers of the oxidative stress. J. Anim. Sci. 97:122-132. https://doi.org/10.1093/jas/ sky408.

Sciorsci, R. L., M. Mutinati, M. Piccinno, E. Lillo, and A. Rizzo.. 2020. Oxidative status along different stages of pregnancy in dairy cows. Large Anim. Rev. 26:223-228.

Sellers, M. D., L. E. Hulbert, and M. A. Ballou.. 2013. Technical note: Determination of preanalysis storage temperature and time allowances for ex vivo innate immune responses. J . Dairy Sci. 96:384-389. https://doi.org/10.3168/jds.2012-5750.

Sheldon, I. M., G. S. Lewis, S. LeBlanc, and R. O. Gilbert.. 2006. Defining postpartum uterine disease in cattle. Theriogenology 65:1516-1530. https://doi.org/10.1016/j.theriogenology.2005.08 .021 .

Shi, L., Y. Xu, C. Mao, Z. Wang, S. Guo, X. Jin, S. Yan, and B. Shi.. 2020. Effects of heat stress on antioxidant status and immune function and expression of related genes in lambs. Int. J. Biometeorol. 64:2093-2104. https://doi.org/10.1007/s00484-020-02000-0.

Silva, T. H., M. L. Celestino, P. R. Menta, R. C. Neves, M. A. Ballou, and V. S. Machado.. 2020. Associations between circulating levels of natural antibodies, total serum immunoglobulins, and polymorphonuclear leukocyte function in early postpartum dairy cows. Vet. Immunol. Immunopathol. 222:110026. https://doi.org/ 10.1016/j.vetimm.2020.110026.

Sordillo, L. M. 2013. Selenium-dependent regulation of oxidative stress and immunity in periparturient dairy cattle. Vet. Med. Int. 2013:154045. https://doi.org/10.1155/2013/154045.

Sordillo, L. M. 2016. Nutritional strategies to optimize dairy cattle immunity. J. Dairy Sci. 99:4967-4982. https://doi.org/10.3168/jds .2015-10354.

Sordillo, L. M., and S. L. Aitken.. 2009. Impact of oxidative stress on the health and immune function of dairy cattle. Vet. Immunol. Immunopathol. 128:104-109. https://doi.org/10.1016/j.vetimm.2008 .10 .305 .

Springman, S. A., J. G. Maddux, M. E. Drewnoski, and R. N. Funston.. 2018. Effects of injectable trace minerals on reproductive performance of beef heifers in adequate trace mineral status. Prof. Anim. Sci. 34:649-652. https://doi.org/10.15232/pas.2018-01752.

Suttle, N. F. 2010. Mineral Nutrition of Livestock. 4th ed. CAB International.

Teixeira, A. G., F. Lima, M. Bicalho, A. Kussler, S. Lima, M. Felippe, and R. Bicalho.. 2014. Effect of an injectable trace mineral supplement containing selenium, copper, zinc, and manganese on immunity, health, and growth of dairy calves. J. Dairy Sci 97:4216-4226. https://doi.org/10.3168/jds.2013-7625.

Vanegas, J. A., J. Reynolds, and E. R. Atwill.. 2004. Effects of an injectable trace mineral supplement on first-service conception rate of dairy cows. J. Dairy Sci. 87:3665-3671. https://doi.org/10 .3168/jds.S0022-0302(04)73505-5.

Wang, H., C. Hu, C. Cheng, J. Cui, Y. Ji, X. Hao, Q. Li, W. Ren, B. Deng, Y. Yin, J. Deng, and C. Tan. 2019. Unraveling the association of fecal microbiota and oxidative stress with stillbirth rate of sows. Theriogenology136:131-137. https://doi.org/10.1016/j .theriogenology.2019.06.028.

Wittrock, J. M., K. L. Proudfoot, D. M. Weary, and M. A. G. Von Keyserlingk.. 2011. Short communication: Metritis affects milk production and cull rate of Holstein multiparous and primiparous dairy cows differently .J. Dairy Sci. 94:2408-2412. https://doi.org/ 10.3168/jds.2010-3697.

Zahorec, R. 2001. Ratio of neutrophil to lymphocyte counts-rapid and simple parameter of systemic inflammation and stress in critically ill. Bratisl. Lek Listy 102:5-14.

Zimbelman, R. B., R. P. Rhoads, M. L. Rhoads, G. C. Duff, L. H. Baumgard, and R. J. Collier. 2009. A Re-evaluation of the Impact of Temperature Humidity Index (THI) and Black Globe Humidity Index (BGHI) on Milk Production in High Producing Dairy Cows. Pages 158-168 in Proc. Southwest Nutr. Man. Conf. University of Arizona. 